\author{
Marzena Lemanowicz \\ Warsaw University of Life Science
}

\title{
INDICATIONS OF CONSUMERS' PROSUMER BEHAVIOUR ON THE FOOD MARKET
}

The objective of this article was to identify examples of prosumer behaviour in the food market, to examine the degree of customer involvement and to measure the attitudes (opinions) of respondents regarding customer engagement in creation/improvement of a product. The most popular activities undertaken by consumers in the field of prosumption were selected and consumer involvement in various types of marketing campaigns organized by producers was determined. The survey was conducted among 320 respondents. The conducted research indicates consumer activity in the field of prosumption; however, respondents mainly manifest behaviour that do not require them to be very active. Sharing opinions on purchased food products is one of the manifestations of prosumer behaviour and these actions are undertaken with great frequency and willingness. The study also identified consumer participation in creating new products and improving existing ones. Over half of the respondents (64.4\%) declared that they participated in these activities, however their participation is rare or very rare. In addition, consumers express positive opinions about the organization of such activities by companies and most of them believe that there are too few such activities on the market.

Key words: prosumption, prosumer behaviour, consumer trends, food market JEL Code: M31, D12

\section{Introduction}

Modern consumption is characterized by the occurrence of many trends that often oppose each other. The basis for distinguishing trends in consumer behaviour primarily includes premises such as: maintaining health, comfort of life, striving for comfort and luxury, individuality, sharing information and knowledge with others. We are currently observing that contemporary consumer behaviour is based not only on passive buying and using food products offered on the market, but also on their co-creation. Consumers have ceased to be passive, uncritical; they have ceased using the ready offerings of enterprises. On the contrary, they are independent, aware, active, creative and manifest their individuality. Through this behaviour they express themselves and want to stand out in society. On the other hand, we observe that producers of food products are increasingly willing to involve customers in the process of creating the products they offer. Consumers are invited to design new products and packaging, or create advertising slogans. Less active consumers take part in campaigns organized by producers and evaluate products on internet forums.

The article concentrated on the phenomenon of prosumption referring to the food market. Even though numerous studies on prosumptive behaviour can be found, those referring directly to the food market are not numerous. The subject has been researched 
among others by Hajduk, Zalega (2013), Bednarz (2018), Luboińska (2018), Troye, Supphellen, Jakubanecs $(2012)^{1}$. The research on consumers' prosumptive behaviour often focuses on the electricity market, electronics economy, e-services, etc..

The objective of the article was to define examples of prosumptive behaviour on the food market and to identify the degree of customer involvement and measure the attitudes (opinions) of respondents regarding customer engagement in creation/improvement of a product. On the basis of the conducted research, the most popular activities undertaken by consumers in the field of prosumption were selected and the involvement of consumers in various marketing campaigns organized by producers, such as participation in creating new products or improving existing ones, was determined. In addition, consumers' opinions about the activities of food industry companies in engaging consumers in various actions were examined.

\section{Review of literature in the field of prosumption}

Prosumption is a term that was created from the combination of two words: production (pro-) and consumption (-sumption). This term is understood as the intertwining of consumption and production acts in one process, until the differences between them are blurred ${ }^{2}$. Prosumption is not a new term. Alvin Toffler introduced this concept into literature in the 1980s. He considered the development of humanity in the context of three successive technological waves, the last of which he directly identified with the emergence of new technologies that enable unlimited communication between individuals through the development of services and departure from mass production. Prosumption characterizes, after agricultural and industrial, the third wave of development of societies ${ }^{3}$. Toffler defined a prosumer as a person willing to take over some tasks that were previously performed by the producer ${ }^{4}$.

Nowadays, prosumption is considered one of the trends in consumer behaviour. It means intelligent consumption and can be described as a form of active participation by consumers in the process of creating a company's offer, so it is any consumer activity initiated in order to co-create new products with the company offering them or modify existing ones ${ }^{5}$. Prosumption is defined as intelligent or innovative consumption; it can be

\footnotetext{
1 M.T. Hajduk, T. Zalega: Zachowania prosumpcyjne polskich konsumentów na rynku produktów żywnościowych, Zarządzanie Innowacyjne w Gospodarce i Biznesie, nr 2(17)/2013, p.41-62; J. Bednarz.: Prosumpcja jako rezultat zmian zachodzących w zachowaniach konsumentów na przykładzie przemysłu spożywczego. Studia Oeconomica Posnaniensia, vol. 5, 1/2017, p.7-24; M. Luboińska: Reakcje i oczekiwania w wybranych grupach konsumentów wobec nowego produktu na rynku żywności funkcjonalnej, Studia Oeconomica Posnaniensia, 12(6)/2018, p.19-41; S.V. Troye S.V., M. Supphellen, A. Jakubanecs: The Consumer as a Co-Producer and Prosumer: Convenience Food Marketing. In: Rudolph T., Schlegelmilch B., Bauer A., Franch J., Meise J. (eds) Diversity in European Marketing. Gabler 2012, p. 179-192.

${ }^{2}$ Cz. Bywalec: Konsumpcja a rozwój gospodarczy i społeczny. C.H. Beck, Warszawa, 2010.

${ }^{3}$ B. Jung, B: Kapitalizm postmodernistyczny, Ekonomista, 5 -6/1997, 715 -735.

${ }^{4}$ A. Toffler: The Third Wave, Bantam Books, Toronto, 1981; A. Toffler: Trzecia fala, PIW, Warszawa, 1986.

${ }^{5}$ A. Baruk., A. Iwanicka: Prosumpcja jako trend konsumencki w opiniach potencjalnych prosumentów, Zeszyty Naukowe Uniwersytetu Szczecińskiego, 41/ 2015, p. 39 -51.
} 
considered both in terms of benefits (exhibitionist prosumption) and cost minimization (rationalization prosumption) ${ }^{6}$.

The determinants of the development of prosumption might be divided into two categories. The first distinguishes so-called general determinants (biological, economic, social, cultural and technological factors) which are connected with consumption. The second category distinguishes the factors which are specific to prosumption, which are $^{7}$ :

- the increase of free time and the need to fulfil it in an attractive way;

- the possibility of working from home and combining it with consumption activities;

- the development of education;

- changes in the work culture and redefining the role of labour in human life: the evolution of labour towards creativity.

A prosumer can be described as a person who purchases goods and services on the one hand, but develops and acquires skills, knowledge and experience on the other. Thanks to these activities, a prosumer benefits from innovation while creating it. A prosumer is also a valuable source of inspiration for producers creating new products. The simultaneous occurrence of these phenomena strengthens external stimuli, e.g. the growing need of people to acquire knowledge and external environmental conditions, such as the increasing number of innovative goods and services. Prosumer activities are strong factors encouraging consumers to be creative and active, and to work effectively, which results in the development of satisfying and modern consumption ${ }^{8}$. Depending on the degree of involvement, prosumers can be divided into 9 :

- the most active innovators who, of their own initiative, are involved in the activities of producers;

- $\quad$ actively responding to actions organized by producers;

- least involved, who only assess and give opinions on existing products and activities of entrepreneurs.

Modern consumers, especially young ones, are active people. They are often referred to as "Generation C". It is a group characterized by above-average creativity, willingness to have control, a tendency to communicate and establish numerous contacts with other people, especially on the Internet (connection). In addition, they have two other features, i.e.: preferring health over intense work, e.g. in corporations (i.e. curation), and the desire to create relationships with friends on the web (community) ${ }^{10}$.

\footnotetext{
${ }^{6}$ T. Zalega: Nowe trendy i makrotrendy w zachowaniach konsumenckich gospodarstw domowych w XXI wieku. Konsumpcja i Rozwój, nr 2(5)/2013, p. 3-21; M. Mitręga: Koncepcja produktów systemowych a prosumpcja. Studia Ekonomiczne, Zeszyty Naukowe Uniwersytetu Ekonomicznego w Katowicach, 262/2016, p. 5-13.

${ }^{7}$ R. Wolny: The development of prosumption on the Polish e-services market. Zeszyty Naukowe SGGW, Polityki Europejskie, Finanse I Marketing, 22(71)/ 2019, p.239 za: Cz. Bywalec, L. Rudnicki: Konsumpcja, PWE, Warszawa 2002, p. 145.

${ }^{8}$ A. Olejniczuk-Merta: Konsumpcja w innowacyjnej gospodarce, Konsumpcja i Rozwój, Instytut Badań Rynku, Konsumpcji i Koniunktur, 1/2011, p.31

${ }^{9}$ E. Szulc: Prosumpcja jako aktywność współczesnych konsumentów - uwarunkowania i przejawy, Nierówności Społeczne a Wzrost Gospodarczy, 31/2013, p.355.

${ }^{10}$ I. Sowa: Determinanty zróżnicowań zachowań prosumenckich młodych konsumentów, Studia Ekonomiczne, Zeszyty Naukowe Uniwersytetu Ekonomicznego w Katowicach, 231/2015, p.123.
} 
The current Generation C consists of the representatives of so-called Generations $\mathrm{Y}$ and $Z$, i.e. people born after the year 1980, who, in Poland, were raised and shaped in a new, non-communist political system. They are fluent in innovative technological solutions, which makes them mobile, flexible and creative.

According to Tapscott ${ }^{11}$ there are several models of behaviour in which prosumption is demonstrated:

- personalization - the customer influences how the product will ultimately look, decides on the properties of the product to reflect their needs;

- hacking products - improving products to suit the needs of the consumer through their modifications;

- crowdsourcing - obtaining information from customers, giving the opportunity to express an opinion on a company's offer;

- $\quad$ collective intelligence - knowledge was created from a combination of choices and opinions of independent consumers.

Modern international literature often refers to the notion of "consumer engagement". It is presented as a measure of business activity ${ }^{12}$, and consumer activity is analysed with reference to purchases they make, incentives directed to the customer, their discussions concerning the brand in social media as well as consumer feedback to the company with modification suggestions aimed at improving the level of provided services or the product itself ${ }^{13}$. Consumers' prosumptive behaviour thus constitutes one of the manifestations of consumer engagement, but the notion is much broader than the notion of prosumption itself.

The active participation of consumers in the process of creating and developing food products increases the effectiveness of these activities. This probably results from the fact that it is rare for people dealing with product design, optimization or marketing to have full knowledge of the final recipient (their wishes, needs and expectations), and also be able to objectively assess the results of their work. Therefore, it is important that target buyers make critical assessments of products throughout the entire development process, and not just at the end of the process.

\section{Role of prosumers in creating new products on the food market}

The food industry is an example of an industry where prosumption is growing relatively slowly. This results from the fact that, compared to the IT industry, where the buyer can "create" a product according to their needs and preferences, foods are products that are

\footnotetext{
${ }^{11}$ D. Tapscott, A.Williams: Wikonomia. O globalnej współpracy, która wszystko zmienia. Wydawnictwa Akademickie i Profesjonalne, Warszawa 2008, p. 69.

${ }^{12}$ V. Kumar, L. Aksoy, B. Donkers, R. Venkatesan, T. Wiesel, S. Tillmanns: Undervalued or Overvalued Customers: Capturing Total Customer Engagement Value, Journal of Service Research, 13(3)/2010, p. 107120; R.J. Brodie., L.D. Hollebeek, B. Jurić. A. Ilić: Customer engagement: conceptual domain, fundamental propositions, and implications for research, Journal of Service Research, 14(3)/2011, p.252-271; S.D. Vivek, S.E. Beatty, R.M. Morgan: Customer engagement: Exploring customer relationships beyond purchase, The Journal of Marketing Theory and Practice, 20(2)/2012, p. 127-145.

${ }^{13}$ L.G. Zomerdijk, Ch.A. Voss: Service Design for Experience-Centric Services, Journal of Service Research, 13(1)/2010, p.67-82.
} 
produced in a uniform and standardized way ${ }^{14}$. On the other hand, the process of shortening the product life cycle observed in the food industry resulting from, e.g. rapidly changing expectations and preferences of consumers, causes a significant rotation and continuous exchange of products. According to estimates of the consulting company IXP Marketing Group, in the world of the FMCG sector (Fast Moving Consumer Goods), a new product appears every three minutes on average, and nearly $80 \%$ of them disappear from the market within a year of their introduction ${ }^{15}$. Also, according to Lazaridis and Drichoutis, ${ }^{16}$ the vast majority of new food products $(72-88 \%)$ is doomed to failure due to low customer satisfaction. This is one of the most important reasons why the activities of food producers should be oriented towards potential buyers. This causes the need for constant involvement of producers in the creation of new products. Cooperation with consumers allows producers to obtain the necessary knowledge about their needs and expectations. Obtaining information from customers in the early stages of product development is a prerequisite for learning their preferences and suggestions relevant to creating new or improved products faster ${ }^{17}$, and skillful and durable cooperation with consumers leads to competitive advantage ${ }^{18}$. Observation of producers' activities in the food sector provides us with many examples confirming the participation of consumers in the creation of new products.

An example of prosumer behaviour affecting the introduction of new food products was the campaign organized by the company Pepsico-Lays. In Poland it began in September 2010, but it appeared in Great Britain earlier (2008). The factor that influenced customers' involvement in the creation of a new product was the fact that the company's financial results had been dropping year by year. This was caused by more and more competition (such as the introduction of private brands on the market). The innovations introduced earlier, without customer involvement, did not bring the expected results. The company's poor financial results led to the creation of an advertising campaign entitled "Come up with a new Lay's flavour!". This campaign engaged consumers through social media to submit individual ideas for a new flavour of the food product. Thus, by stimulating the activity of its customers, the company has launched new products developed together with prosumers ${ }^{19}$.

The firm Dr. Oetker also involved consumers in the launching of a new product. The action called "Duel of Flavours" took place in Poland in 2015. Prosumers had an impact on which of the two flavours of pizza (Hawaiin or Chicken Thai) was to be introduced to the offer permanently. As in the case of Lay's crisps, the campaign was conducted on the Internet, on a specially created website and on the company's fan page. Apart from voting, prosumers had to justify their choice. The flavour with the largest

\footnotetext{
${ }^{14}$ J. Bednarz: Prosumpcja jako rezultat zmian zachodzących w zachowaniach konsumentów na przykładzie przemysłu spożywczego. Studia Oeconomica Posnaniensia, vol. 5, 1/2017, p.17.

${ }^{15}$ M. Lindstrom: Zakupologia. Prawdy i kłamstwa o tym, dlaczego kupujemy, Wydawnictwo Znak, Kraków 2009, p. 35.

${ }^{16}$ P. Lazaridis, A.C. Drichoutis: Food Consumption Issues in the 21st Century, [w:] Soldatos, P., Rozakis, S. (red.) The Food Industry in Europe, Agricultural University of Athens, Athens 2005, p.31.

${ }^{17}$ L. Miotti , F.Sachwald: Cooperative R\&D: why and with whom? An integrated framework of analysis. Research Policy, .32/2003, p.1489.

${ }^{18}$ D. Henard, P. Dacin: Reputation for Product Innovations: Its Impact on Consumers. Product Development \& Management Association, 27/2010, p.321-335.

${ }^{19} \mathrm{https} / / /$ socialmediasocjologia.wordpress.com/2014/05/19/wymysl-nowy-smak-lays/, (dostęp: 15.02.2020).
} 
number of customer votes remained in the sales offer ${ }^{20}$. Another company, Zott asked consumers to participate in a competition to design a bottle of Jogobella yoghurts. The design had to be made using the application on the competition website, and Jogobella yoghurts in bottles, the design of which was created by consumers, were available in stores throughout the country. In another competition, the company asked consumers to create a new flavour for Monte desserts. In a special application on the competition website, prosumers had to design a label and choose delicious additions to the product (create a new flavour).

Prosumers could also decide on the choice of a new type of alcoholic beverage. From among beer suggestions, such as "Żywiec Marcowe", "Żywiec Białe" and "Żywiec Bock" consumers were to choose one type. Despite the advantage in the number of votes of one of the above-mentioned products, all three flavours were introduced to the market at the request of consumers ${ }^{21}$. Another of the many examples showing how prosumers influence the marketing strategy of food industry companies is Coca-Cola, which encouraged consumers to take an active part in changing the traditional taste of the Coca-Cola drink. A similar concept was also introduced by Masterfoods, organizing the Internet campaign "Global colour vote" that involved voting for a new colour (taste) of "M\&M's". Prosumers could also reveal their preferences regarding the limited offer of "Nespresso" coffee by voting for "Cioccorosso" (coffee with aromas of red fruits and dark chocolate), "Masala Chai" (aromas of cinnamon, anise, cloves) and "Liminto" (aromas of mint and lime). Cioccorosso won in Poland $59 \%$ of 788 people participating in the campaign voted for it. Other versions of flavours gained much fewer votes: Masala Chai gained $20 \%$ of votes, while Liminto $22 \%{ }^{22}$. The campaign organized by "Reds" that involved encouraging consumers to design their own beer can, is yet another example ${ }^{23}$.

Depending on the degree of consumer involvement in the development of the food industry, one can distinguish very active prosumers whose creativity contributes to the introduction of new products or packaging. Another group consists of consumers who are not creative on their own but only respond to the activities undertaken by food producers. The least active prosumers are limited to rating and reviewing products on online forums or store pages; however, their activity is very useful for other consumers.

\section{Material and methods}

To achieve the objectives set out in this article, in addition to reviewing literature related to the subject of prosumption, a survey was conducted among consumers. The research technique was an internet survey, and the research tool was a questionnaire that was placed on a popular social networking site. Due to the small number of people surveyed (unrepresentative studies), the results are for reference only, and the conclusions drawn

\footnotetext{
${ }^{20}$ https://www.oetker.pl/pl-pl/nasza-firma/biuro-prasowe/nowosci-biuro-prasowe/nowosc-biuroprasowe/n/Marken-Und-Produkt-News/pojedynek-smakow-niecodzienna-akcja-promocyjna-wspierajacawprowadzenie-nowych-smakow-pizzy-gu, (dostęp: 15.02.2020)

${ }^{21} \mathrm{http}$ ///warianty.zywiec.com.pl/, (dostęp: 15.02.2020).

${ }^{22} \mathrm{http}: / /$ rynekkawy.pl/klienci-wybierali-ka/, (dostęp: 15.02.2020).

${ }^{23}$ M. Lemanowicz, J. Szwacka-Mokrzycka: Identification of leading consumer trends on the food market, [w:] Economic Science for Rural Development. Proceedings of the International Scientific Conference, vol. 51/2019, p. 294.
} 
relate only to the surveyed population. 320 respondents took part in the survey, including 244 women and 76 men. Most respondents were 18-26 years old (76\%), significantly fewer respondents were 27-36 years old (12.5\%), while people over 50 years of age and between 46 and 50 years of age and under 18 constituted respectively $3.8 \%, 2.8 \%$ and $3 \%$. The least numerous group consisted of people aged 36-44 (1.9\%). Over half of the respondents $(53 \%)$ indicated a city of over 500,000 residents as their place of residence; $14 \%$ lived in cities from 150-500,000 residents and $12.8 \%$ of respondents lived in the countryside. The remaining respondents lived in smaller cities, i.e. up to 50,000 and 50$-150,000$ residents. Considering the young age of the respondents, most of them were during their studies $(62.2 \%)$, and $26.3 \%$ had higher education. The respondents provided answers to 16 questions included in the questionnaire.

\section{Research results}

The conducted research identified various manifestations of consumers' prosumer activities. This confirms the varying degrees of consumer involvement in these activities, from activities that greatly involve consumers to more passive activities of merely sharing opinions on purchased products. Consumers today have many opportunities to share their insights on purchased products. Producers' websites, fan pages of a given brand or specific product, numerous social media platforms are just some of the places where consumers can express their opinions. Among the respondents, more than half (53.8\%) declared that they expressed opinions on new food products. The most numerous groups of respondents sharing their opinions consisted of people who defined the frequency of these behaviours as frequent $(40 \%)$, rare $(28 \%)$, and whenever it is possible (18\%). $14 \%$ of respondents express their opinions very rarely. Respondents, regardless of the frequency of expressing their opinions, indicated that they most often share their opinion on private profiles in social media, among their friends (this answer was chosen by $73.9 \%$ of people). The respondents also indicated that they share their opinions in online discussion groups, on a company's fan page and direct messages to food producers (Chart 1).

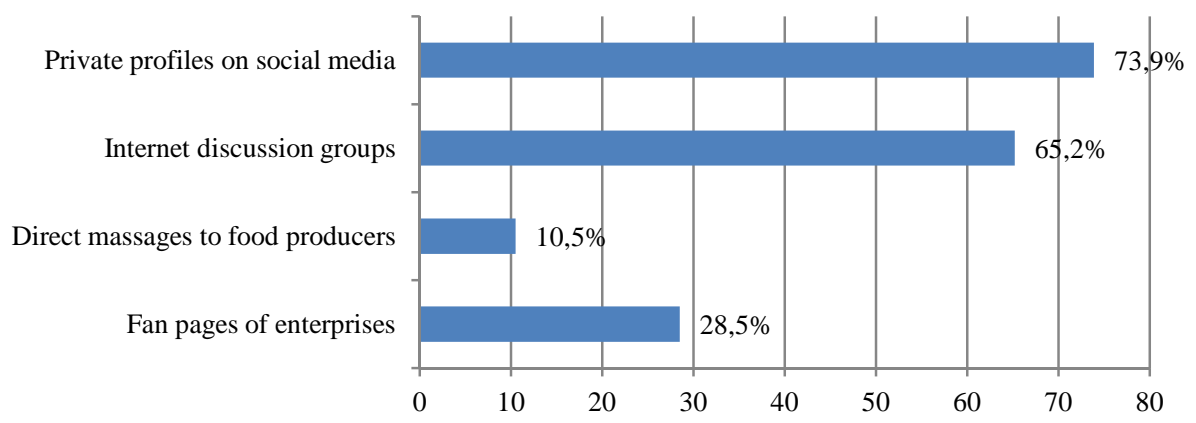

Chart 1. Methods of sharing opinions on purchased food products $(\mathrm{N}=172)$

Source: The author's own study.

The results of the conducted research indicate that expressing opinions on purchased food products is one of the manifestations of prosumer behaviour and these actions are taken with great frequency and willingness. However, the issue of prosumption clearly indicates activities based on greater consumer activity than just expressing opinions. That is why the 
study identified the participation of consumers in creating new products and improving existing ones. Over half of the respondents $(64.4 \%, 206$ people) declared that they participated in these activities, but the frequency of these activities is not high. Of those involved in these activities, $36 \%$ do so rarely and the same percentage of respondents do it very rarely. $17 \%$ of the respondents present their suggestions whenever it is possible, and only $11 \%$ of the respondents do so frequently. The above responses of the respondents clearly indicated that only a small proportion of respondents regularly participate in marketing campaigns aimed at improving products or creating new products. Participation in the creation of new products can take place in many ways. Most often, the respondents take part in the design of packaging, their appearance and labels (67.5\%). They also design new products, e.g. new flavours (47.6\%), and also take part in the creation of advertising slogans (Chart 2).

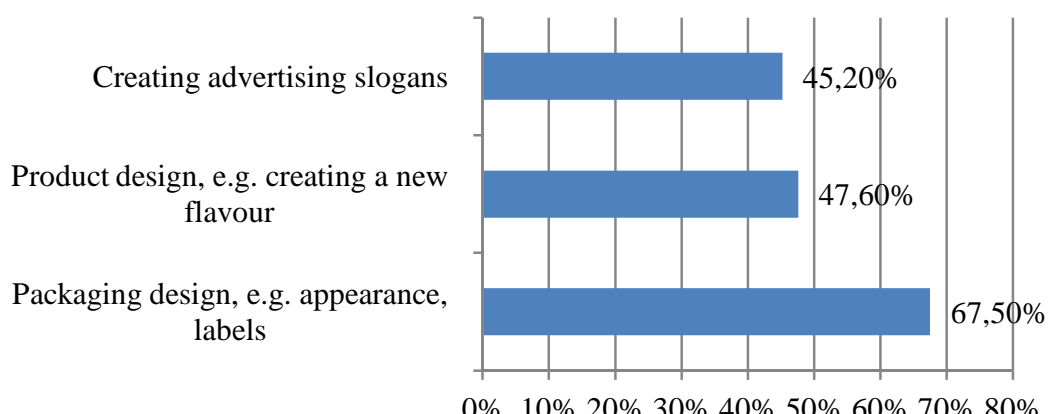

Chart 2. Participation of respondents in creating new products $(\mathrm{N}=206)$

Source: The author's own study.

An important element of the research was to find out the respondents' opinions on the activities of food industry companies involving consumers. Likert's scale was used in this question and five statements were submitted for assessment. Table 1 presents the answers obtained.

Table 1. Respondents' opinions regarding activities in the field of prosumption undertaken by food sector companies $(\mathrm{N}=320)$

\begin{tabular}{|c|c|c|c|c|c|}
\hline Specification & $\begin{array}{l}\text { I definitely } \\
\text { disagree }\end{array}$ & $\begin{array}{l}\text { I rather } \\
\text { disagree }\end{array}$ & $\begin{array}{l}\text { I neither } \\
\text { agree nor } \\
\text { disagree }\end{array}$ & $\begin{array}{l}\text { I rather } \\
\text { agree }\end{array}$ & $\begin{array}{c}\text { I definitely } \\
\text { agree }\end{array}$ \\
\hline $\begin{array}{l}\text { Enterprises take their customers' } \\
\text { opinions about products into account }\end{array}$ & $11,3 \%$ & $6,6 \%$ & $28,5 \%$ & $24,5 \%$ & $29,1 \%$ \\
\hline $\begin{array}{l}\text { Enterprises often involve their } \\
\text { customers in activities aimed at } \\
\text { improving/creating a product }\end{array}$ & $12,2 \%$ & $15,0 \%$ & $24,5 \%$ & $30,0 \%$ & $18,3 \%$ \\
\hline $\begin{array}{l}\text { I believe that participation of } \\
\text { consumers in creation/improvements } \\
\text { of products is right }\end{array}$ & $9,5 \%$ & $4,7 \%$ & $6,6 \%$ & $31,0 \%$ & 48,2 \\
\hline $\begin{array}{l}\text { There are many activities on the } \\
\text { market that involve consumers }\end{array}$ & $49,1 \%$ & $20,7 \%$ & $22,5 \%$ & $5,6 \%$ & $2,1 \%$ \\
\hline
\end{tabular}

Source: The author's own elaboration. 
Not all respondents agreed that companies take into account their opinions regarding purchased products. However, those who disagreed with this fact were definitely fewer in number. A fairly large number of respondents could not determine whether they agreed with this statement or not $(28.5 \%)$. Despite this, the majority of respondents rather agreed that enterprises very often involve their customers in marketing campaigns aimed at creating/improving products. Almost half of the respondents $(48.2 \%)$ strongly agreed that the participation of consumers in creating/improving products is the right course of conduct for companies, which proves that they appreciate such activities. At the same time, most disagree that there are too many activities engaging consumers in this type of campaigns on the market. Undoubtedly, this indicates a positive attitude of the respondents to this type of activities, which can translate into an increase in the popularity of a given brand or company.

\section{Conclusions}

Prosumption is considered one of the trends in consumer behaviour. It can be described as a form of active participation of consumers in the process of creating a company's offer. Depending on the degree of consumer involvement, one can distinguish very active prosumers participating in activities aimed at creating or improving new products or packaging, and those less active who limit their activities to sharing their opinions on forums, fan pages of companies or brands, etc. Considering the specifics of behaviours, in particular of young consumers, it can be stated that prosumption is a trend that will develop intensely. The younger generation (Generation Y, Z) is often referred to as the "online generation". They are active, creative people, willing to express themselves, unafraid to enter into a dialogue with enterprises and honestly inform them of their opinions. Development and dissemination of prosumption is favoured by dynamically developing techniques and the growth of information technology. The active participation of consumers in the process of creating and developing food products increases its effectiveness. This is due to the fact that people dealing with product design, optimization or marketing do not always have a full understanding of the final recipient (their needs and expectations), and they may also fail to objectively assess the results of their work. It is therefore extremely important to include target buyers in activities related to creating new or improving existing products.

On the other hand, enterprises, by engaging consumers in numerous marketing campaigns, gain new customers, focus their attention on their brand and, knowing the needs and preferences of buyers better, can count on their stable presence on the market. Prosumer activities can be treated by the consumer as a kind of entertainment, and Internet access is often required to participate in them. In the opinion of the author of this article, food industry companies should involve consumers in the creation and improvement of products more often; however, they should also consider ways of rewarding consumers for their creativity. Perhaps consumers should be included, and a business model should be created that would allow them to participate in the profits from the sale of products created with their participation. The conducted research indicates consumer activity in the field of prosumption; however, respondents mainly manifest behaviours that do not require them to be very active (sharing their opinions). 
Participation in other marketing campaigns such as creating new products or improving existing ones are undertaken by most respondents rarely or very rarely. Furthermore, consumers express positive opinions about the organization of these types of activities by companies and most of them believe that there are too few of such activities on the market and they are barely visible.

\section{Bibliography}

Baruk A., A. Iwanicka: Prosumpcja jako trend konsumencki w opiniach potencjalnych prosumentów, Zeszyty Naukowe Uniwersytetu Szczecińskiego, 41/ 2015

Bednarz J.: Prosumpcja jako rezultat zmian zachodzących w zachowaniach konsumentów na przykładzie przemysłu spożywczego. Studia Oeconomica Posnaniensia, vol. 5, 1/2017

Brodie R.J., L.D. Hollebeek, B. Jurić. A. Ilić: Customer engagement: conceptual domain, fundamental propositions, and implications for research, Journal of Service Research, 14(3)/2011

Bywalec Cz.: Konsumpcja a rozwój gospodarczy i społeczny. C.H. Beck, Warszawa, 2010

Hajduk M.T., T. Zalega: Zachowania prosumpcyjne polskich konsumentów na rynku produktów żywnościowych, Zarządzanie Innowacyjne w Gospodarce i Biznesie, nr 2(17)/2013

Henard D., P. Dacin: Reputation for Product Innovations: Its Impact on Consumers. Product Development \& Management Association, 27/2010

Jung, B.: Kapitalizm postmodernistyczny, Ekonomista, 5-6/1997

Kumar V., L. Aksoy, B. Donkers, R. Venkatesan, T. Wiesel, S. Tillmanns: Undervalued or Overvalued Customers: Capturing Total Customer Engagement Value, Journal of Service Research, 13(3)/2010

Lazaridis P., A.C. Drichoutis: Food Consumption Issues in the 21st Century, [w:] Soldatos, P., Rozakis, S., (red.) The Food Industry in Europe, Agricultural University of Athens, Athens 2005

Lemanowicz M., J. Szwacka-Mokrzycka: Identification of leading consumer trends on the food market, [w:] Economic Science for Rural Development. Proceedings of the International Scientific Conference, vol. 51/2019, Jelgava, Latvia

Lindstrom M.: Zakupologia. Prawdy i kłamstwa o tym, dlaczego kupujemy, Wydawnictwo Znak, Kraków 2009

Luboińska M.: Reakcje i oczekiwania w wybranych grupach konsumentów wobec nowego produktu na rynku żywności funkcjonalnej, Studia Oeconomica Posnaniensia, 12(6)/2018

Miotti L., F.Sachwald: Cooperative R\&D: why and with whom? An integrated framework of analysis. Research Policy, 32/2003

Mitręga M.: Koncepcja produktów systemowych a prosumpcja. Studia Ekonomiczne, Zeszyty Naukowe Uniwersytetu Ekonomicznego w Katowicach, 262/2016

Olejniczuk-Merta A.: Konsumpcja w innowacyjnej gospodarce, Konsumpcja i Rozwój, Instytut Badań Rynku, Konsumpcji i Koniunktur, 1/2011

Sowa I.: Determinanty zróżnicowań zachowań prosumenckich młodych konsumentów, Studia Ekonomiczne, Zeszyty Naukowe Uniwersytetu Ekonomicznego w Katowicach, 231/2015

Szulc E.: Prosumpcja jako aktywność współczesnych konsumentów - uwarunkowania i przejawy, Nierówności Społeczne a Wzrost Gospodarczy, 31/2013

Tapscott D., A. Williams: Wikonomia. O globalnej współpracy, która wszystko zmienia. Wydawnictwa Akademickie i Profesjonalne, Warszawa 2008

Toffler A.: The Third Wave, Bantam Books, Toronto, 1981

Toffler A.: Trzecia fala, PIW, Warszawa, 1986

Troye S.V., M. Supphellen, A. Jakubanecs: The Consumer as a Co-Producer and Prosumer: Convenience Food Marketing. In: Rudolph T., Schlegelmilch B., Bauer A., Franch J., Meise J. (eds) Diversity in European Marketing. Gabler 2012 
Vivek S.D., S.E. Beatty, R.M. Morgan: Customer engagement: Exploring customer relationships beyond purchase, The Journal of Marketing Theory and Practice, 20(2)/2012

Wolny R.: The development of prosumption on the Polish e-services market. Zeszyty Naukowe SGGW, Polityki Europejskie, Finanse I Marketing, 22(71)/ 2019

Zalega T.: Nowe trendy i makrotrendy w zachowaniach konsumenckich gospodarstw domowych w XXI wieku. Konsumpcja i Rozwój, 2(5)/2013

Zomerdijk L. G., Ch.A. Voss: Service Design for Experience-Centric Services, Journal of Service Research, 13(1)/2010

https://socialmediasocjologia.wordpress.com/2014/05/19/wymysl-nowy-smak-lays/,(dostęp: 15.02.2020)

https://www.oetker.pl/pl-pl/nasza-firma/biuro-prasowe/nowosci-biuro-prasowe/nowosc-biuroprasowe/n/Marken-Und-Produkt-News/pojedynek-smakow-niecodzienna-akcja-promocyjnawspierajaca-wprowadzenie-nowych-smakow-pizzy-gu, (dostęp: 15.02.2020)

http://warianty.zywiec.com.pl/, (dostęp: 15.02.2020)

http://rynekkawy.pl/klienci-wybierali-ka/, (dostęp: 15.02.2020)

\section{Przejawy zachowań prosumpcyjnych konsumentów na rynku żywności}

\section{Streszczenie}

Celem artykułu było zidentyfikowanie przykładów zachowań prosumpcyjnych na rynku żywności, określenie stopnia zaangażowania konsumentów w te działania i pomiar postaw (opinii) respondentów dotyczących zaangażowania klienta w tworzenie/ulepszanie produktów. $\mathrm{Na}$ podstawie przeprowadzonych badań wyłoniono najbardziej popularne działania podejmowane przez konsumentów z zakresu prosumpcji, określono zaangażowanie konsumentów w różnego rodzaju akcje marketingowe organizowane przez producentów. Badanie ankietowe przeprowadzono w grupie 320 respondentów.

Wyniki przeprowadzonych badań wskazują, że wyrażanie opinii na temat zakupionych produktów spożywczych jest jednym $\mathrm{z}$ przejawów zachowań prosumpcyjnych i działania te podejmowane są $\mathrm{z}$ dużą częstotliwościa i chęcią. W badaniu zidentyfikowano również uczestnictwo konsumentów w kreowaniu nowych produktów i ulepszaniu już istniejących. Ponad połowa respondentów $(64,4 \%, 206$ osób) zadeklarowała, ze uczestniczy w tych działaniach, jednakże udział ten jest rzadki bądź bardzo rzadki. Przeprowadzone badania wskazują na aktywność konsumentów w zakresie prosumpcji, jednakże respondenci przejawiają głównie zachowania nie wymagające od nich dużej aktywności. Ponadto konsumenci wyrażaja pozytywne opinie na temat organizowania tego typu działań przez firmy i większość z nich uważa, że na rynku jest ich za mało.

Słowa kluczowe: prosumpcja, zachowania prosumpcyjne, trendy konsumenckie, rynek żywności JEL Codes: M31, D12

Information about author:

Dr Marzena Lemanowicz

Warsaw University of Life Sciences

Institute of Economics and Finance

Department of Development Policy and Marketing

e-mail: marzena_lemanowicz@sggw.edu.pl

ORCID: 0000-0002-5114-9185 